Reading between the Lines: Analyzing the Supreme Court's Views on Gender Discrimination in Employment, 1971-1982

Author(s): Vicki Lens

Reviewed work(s):

Source: Social Service Review, Vol. 77, No. 1 (March 2003), pp. 25-50

Published by: The University of Chicago Press

Stable URL: http://www.jstor.org/stable/10.1086/345703

Accessed: $1 6 \longdiv { / 1 0 / 2 0 1 2 ~ 1 5 : 4 3 }$

Your use of the JSTOR archive indicates your acceptance of the Terms \& Conditions of Use, available at http://www.jstor.org/page/info/about/policies/terms.jsp

JSTOR is a not-for-profit service that helps scholars, researchers, and students discover, use, and build upon a wide range of content in a trusted digital archive. We use information technology and tools to increase productivity and facilitate new forms of scholarship. For more information about JSTOR, please contact support@jstor.org. 


\title{
Reading between the Lines: Analyzing the Supreme Court's Views on Gender Discrimination in Employment, 1971-1982
}

\author{
Vicki Lens \\ Columbia University School of Social Work
}

\begin{abstract}
Supreme Court decisions can be read on two levels: as prescriptive statements of what legally can or cannot be done and as discourses that define the Court's view of social problems. This article explores this latter role through a content analysis of Court decisions that directly address the struggle for women's equality in the workplace during the 1970s. As it formulated the legal rules applicable to gender discrimination, the Court also gave social and political meaning to the concept of equality. Examining this process of problem definition in the judicial arena provides a different perspective for viewing Supreme Court decisions.
\end{abstract}

The decade of the 1970s was a seminal period in the modern feminist movement. As increasing numbers of women entered the workforce, long-standing stereotypes and perceptions were upended and cultural images revised. The Supreme Court played an especially active role in this process as the new feminist movement, like the civil rights movement, frequently brought its grievances to the judicial system (Burstein 1991; Walsh 1998; Ferree and Hess 2000). In Reed v. Reed (404 U.S. 71 [1971]), the Court held for the first time that the Constitution forbids discrimination against women. With this beginning, the Court laid the legal foundation through the 1970 s for how the Constitution and newly

Social Service Review (March 2003).

(C) 2003 by The University of Chicago. All rights reserved.

0037-7961/2003/7701-0002\$10.00 
enacted laws, such as the Equal Pay Act of 1963 (U.S. Public Law 8838, 77 Stat. 56, codified at 29 U.S.C. 206 [a]) and the Civil Rights Act of 1964 (U.S. Public Law 88-352, 78 Stat. 241), were to be construed in the context of gender discrimination (Goldstein 1989). ${ }^{1}$

However, the Supreme Court did more than set legal parameters. It also engaged in a spirited public discourse about the problem of gender discrimination and the meaning of equality. As Deborah Stone explains, "causal stories" are created for every social problem to explain the harm being caused, who is causing it, and the moralities involved (1989, p. 282). These narratives contain assumptions, based on certain cultural themes and values, about how people should behave. Like public actors in other venues, the Court also engages in this subjective process of problem definition. As Theda Skocpol observes, the Court is a "profoundly rhetorical institution . . . affected by moral understandings deeply embedded in political discourse" (1995, p. 128). In short, while Court decisions are, of course, about the law, they are also narratives about cultural norms and values.

Supreme Court decisions can thus be read on two levels. First, they can be understood prescriptively as statements of what the law says, what legally can or cannot be done. Legal scholars and lawyers devote much of their time to understanding the law in this way. Second, the decisions can be read constructively as discourses that define the parameters of social problems and contain images and archetypes of groups and individuals. This way of reading decisions can be especially instructive to those engaged in or affected by the policy-making process, including social workers.

This article explores the Court's constructive role through a content analysis of cases that directly address the struggle for women's equality in the workplace during that crucial decade of the 1970s, when the Court began weighing in on the issue of gender discrimination. The outcomes of those cases are well documented in legal and other scholarly literature (Goldstein 1989; Otten 1993; Seymour 1997; Ferree and Hess 2000). Less examined is the second way to read these decisions: as documents that reveal the judiciary's view of the social problem of gender discrimination. I examine how the Court gave social and political meaning to the notion of equality as it attempted to apply it to a labor market that included increasing numbers of women, but where many of the old rules and stereotypes still applied. I look at what role the Court played in challenging these stereotypes and redrawing women's role in society.

Examining these decisions serves a dual purpose. First, it provides a systematic way of studying the process of problem definition in the judicial arena, thus enhancing our knowledge of the policy-making process. Scholars have long recognized the Supreme Court as a policymaking institution (Dahl 1957; Casper 1976; McCloskey 1994; Abrams 
1997; Rosenberg 1991). Virtually all of our political, economic, and social questions turn into legal ones. This power is by design, with the Constitution reserving for the Court a key and authoritative role in deciding disputes (Segal and Spaeth 1993; McCloskey 1994). By serving as a forum for resolving disputes over social issues, the Court's rulings take on "a moral dimension that transcends their technological significance as legal precedents [as various public actors] seek to have the rule of law reflect their own conception of justice" (Kay 1985, p. 41). In short, the Court is an important arena for studying not only the evolution of legal principles but also the process of policy making.

Second, reading between the lines of Supreme Court decisions from the 1970s can also help us understand this period of immense social change in the roles and status of women. It provides another way of looking at the events of this decade, as seen through the eyes of the Supreme Court justices whose rulings, and the language used to explain them, helped to shape the public discourse on gender discrimination.

\section{Historical Context}

The 1970s was in many ways the heyday of the modern women's movement. Although the 1960s signified its birth, by the 1970s it had blossomed into a powerful and organized movement (Boneparth 1982). While the early feminists of the 1960s were often ridiculed and isolated from the political mainstream, by the 1970s their organizations, such as the National Organization for Women, had become part of the national political landscape, helping to shape governmental policy (Boneparth 1982). With more women in the workplace than out of it (a historical first), there was also increased attention to women's issues in the employment context (Wandersee 1988).

Feminists began the decade with the support of the Democratic and Republican parties. Both parties backed the Equal Rights Amendment (ERA; Wandersee 1988). Successive presidents, beginning with Kennedy in 1963, and including Nixon, Ford, and Carter, found it politically advantageous to appoint various task forces and advisory committees on women, helping to elevate the concerns of women to the national level and spurring the passage of progressive legislation (Boneparth 1982; Ferree and Hess 2000). Although relations with women's groups were not always smooth (President Carter's first liaison for women's issues was dismissed for criticizing him), Republican and Democrat presidents alike publicly professed support for women's rights throughout the 1970s (Boneparth 1982).

During this decade, Congress was also active in pursing an agenda that incorporated equal rights for women. ${ }^{2}$ The 1970 s saw successive pieces of legislation designed specifically to help women in such diverse areas as sports, science, employment, and financial services, to name a 
few. Examples include Title IX of the Civil Rights Act (Title IX of the Education Amendments of 1972, U.S. Public Law 92-318, 86 Stat. 373, codified at 20 U.S.C. 1681), prohibiting sex discrimination in any educational program that receives federal funds; the Equal Credit Opportunity Act of 1974 (U.S. Public Law 93-495, 88 Stat. 1521, codified at 15 U.S.C. 1691), prohibiting discrimination in credit transactions; and the Science and Engineering Equal Opportunities Act of 1980 (U.S. Public Law 96-516, 94 Stat. 3010, codified at 42 U.S.C. 1885), designed to encourage women's participation in science. The push for women's equality spread to even such traditionally male-dominated institutions as the military. Enlistment quotas for women were lifted, women were allowed to enlist at the same age as men, and they were granted permission to enter military academies (Freeman 1982).

Organized opposition to the women's movement surfaced in reaction to its victories. The success of the Equal Rights Amendment in Congress, which passed the House and Senate in 1972 with overwhelming majorities, sparked an antifeminist movement that helped ultimately to defeat it in the states (Wandersee 1988). Partisan splits began to appear during the mid 1970s with the emergence of the new right in the Republican party, the increasing visibility of such conservative groups as Jerry Falwell's Moral Majority, and an antiabortion movement galvanized by the Supreme Court's 1973 decision in Roe v. Wade (410 U.S. 959 [1973]).

Thus, whereas the decade began with both parties supporting women's rights, it ended with the election of a Republican president who actively solicited support from antifeminists (Ferree and Hess 2000). Likewise, the ERA, viewed as a certain victory in the early 1970s, faltered and failed to meet the 7-year state ratification deadline in 1979, as well as an extended deadline in 1982 (Boneparth 1982). Although progressive legislation, such as the Pregnancy Discrimination Act of 1978 (U.S. Public Law 95-555, 92 Stat. 2076, codified at 42 U.S.C. 2000), was passed, such legislation was increasingly met with resistance by the end of the decade.

The Supreme Court was an active participant throughout the decade, routinely tackling the issues of gender and discrimination, both in the personal sphere (including abortion and family law) and the public sphere of employment. Five out of nine justices were newcomers to the Court during this decade, including Chief Justice Warren Burger, appointed in 1969 by President Nixon (Supreme Court 2002). The Burger Court came on the heels of the Warren Court, perceived by many as one of the most liberal and activist courts in history (Eskridge 1991; Yalof 1999). Nixon made three more appointments: Harry Blackmun in 1970 and William Rehnquist and Lewis Powell in 1972. In 1975, President Ford appointed John Paul Stevens (Supreme Court 2002). ${ }^{3}$

The other justices on the Court during this decade included William Brennan and Stewart Potter, appointed in 1956 and 1958, respectively, 
by Eisenhower; Byron White, appointed by Kennedy in 1962; and Thurgood Marshall, appointed by Johnson in 1967 (Supreme Court 2002). The longest-serving justice on the Court was William Douglas, appointed by President Roosevelt in 1939, who left the Court in 1975 and was replaced by Justice Stevens (Supreme Court 2002). Thus, Republican appointees predominated on the Court during this decade, first by a $6-3$, and then by a $6-2$, margin.

However, women's rights found support among both Democrats and Republicans, at least in the beginning of the decade. Moreover, as legal scholars have observed, presidents are often surprised by the ideology of their appointees (Eskridge 1991; Yalof 1999; Yoo 2000). Thus, conclusions concerning the ideological tilt of the Court toward women cannot be based solely on the fact that it was composed overwhelmingly of justices appointed by Republican presidents. To be sure, ideology does play a role in judicial decision making, but its role is much more complex than simply affixing a partisan label to a particular justice.

\section{Theoretical Framework}

How judges make decisions, and whether ideology is a factor, is a subject of some controversy among scholars. The legal, or positivist, model assumes that judicial decision making is an objective, rational enterprise. Past cases, or precedent, determine the outcome of present cases because the doctrine of stare decisis requires judges to apply established principles of law to all future cases (Wasby 1988; McCloskey 1994). Judges are mechanistic in their approach, restrained by rules that prevent their own subjective beliefs and opinions from seeping into their decisions. Legal education is primarily dominated by this method.

In contrast, legal realists see law not as a static rational set of rules, but as evolving along with changing social, economic, and political conditions (Kalman 1986). ${ }^{4}$ They view judicial decision making more dynamically, recognizing that the law is but one factor that determines case outcomes. The Court is viewed primarily as a political institution that, as described by Robert Dahl, is "inevitably a part of the dominant national alliance" (1957, p. 293; see also Rosenberg 1991). The values and ideologies of individual justices also form an integral part of the deliberative process, affecting its decisions. Laws, precedent, and even legislative history are open to multiple interpretations, and the subjective attitudes and beliefs of the justices prevail when choosing an interpretation (Segal and Spaeth 1993).

There is a substantial body of research supporting the impact of extralegal factors on judicial decision making (Schubert 1965; Gibson 1978; Segal 1984; Segal and Cover 1989; Cross and Tiller 2000; Romero 2000). An example is Segal and Spaeth's analysis (1993) of Supreme Court decisions since 1953, which demonstrates that whether a judge 
is liberal or conservative will be a more accurate predictor of case outcomes than any specific facts or legal principles. Other studies demonstrate that who the litigants are can also affect outcomes. The haves are more likely to win than the have-nots (Galanter 1974; Wheeler et al. 1987; Sheehan, Mishler, and Songer 1992). When the government is a party, it is more likely to win than businesses, who in turn are more successful than individuals (Songer and Sheehan 1992; Songer 1999).

However, quantitative measurements of outcomes, as used in the above-cited studies, do not capture the particular ideologies, cultural beliefs, and other qualitative aspects of a decision, which can be as central to its outcome as specific legal rules. One way to uncover this discursive aspect of decisions is to examine its "symbolic or expressive content" (Sunstein 1996, p. 2023). That content is often easy to spot because decisions past and present frequently contain unambiguous expressions of moral understandings and cultural assumptions. The Court's view in Bradwell v. Illinois (83 U.S. [16 Wall] 442 [1873]) that "the natural and proper timidity and delicacy which belongs to the female sex evidently unfits it for many of the occupations of civil life" is one such example (p. 444). A more recent example is Bowers v. Hardwick (478 U.S. 186 [1986]), where the Court upheld the right of a state to ban sodomy based on that state's belief that homosexuality is morally abhorrent. But such anecdotal examples do not illustrate the complexity and the regularity with which the Court frames the issues before it in terms of ideology, values, and cultural assumptions.

To systematically examine this process, I draw on the theoretical construct of social constructionism, which emphasizes the subjective nature of social problems and the use of language and narratives by public actors to define a particular social problem (Berger and Luckman 1966; Spector and Kitsuse [1977] 1987; Rochefort and Cobb 1993; Best 1995; Loseke 1997). Social conditions are transformed into social problems and are given shape, as well as meaning, through language. To understand this process, constructionist researchers dissect the language of the public discourse to reveal underlying themes, moralities, and values (see, e.g., Gamson and Modigliani 1989; Burstein, Bricher, and Einwohner 1995; de Goede 1996; Loseke 1999).

I apply this approach to Supreme Court decisions on gender discrimination, exploring how the Court, like other actors in the public arena, wove together a mix of facts, images, values, and assumptions about women to support its definition of equality. Analyzing this aspect of its decisions adds a different dimension and depth to our understanding of the extralegal function of the Court and its role as a policy maker, both generally and in the context of the women's rights movement. 


\section{Methodology}

The study focuses on the early decades of the modern feminist movement, beginning in 1971. In 1971, the Supreme Court decided for the first time that the Constitution protects women against gender discrimination. Although the new feminist movement first emerged in the 1960s, it was not until 1971 that the Court heard its first case on gender discrimination. That case was brought by now Justice Ginsberg (Seymour 1997). The study ends in 1982, the date identified by scholars as marking the transition of the movement from a period of growth and change to one of defensive retrenchment as a more hostile and politically conservative climate took hold (Ferree and Hess 2000). Including the years 1980-82 also permits examination of cases that were brought in the 1970s but, because of the time lag inherent in the appeals process, did not make their way to the Court until the early 1980s. This time period marks a period of tremendous social change in which the Court played a major role, making it a useful and instructive period for study. ${ }^{5}$

The data for this study include all Supreme Court opinions published between 1971 and 1982 that explicitly address any issue relating to women and the workplace, such as terms and conditions of employment and the amount or availability of benefits, including employer-sponsored benefits or governmental benefits related to work (e.g., Social Security benefits). The data also include opinions that are based on the equal protection or due process clauses of the U.S. Constitution; federal statutory equal opportunity law, including the Civil Rights Act of 1964; and the Equal Pay Act of 1963. Opinions are also included that involve either a private employer or a governmental unit as an employer or provider of work-related benefits or that involve an educational opportunity directly relevant to employment. Also covered are so-called reverse discrimination cases in which men challenged employers or government for not providing them or their families with the equivalent benefits provided to women. These cases are included because they also address gender roles and expectations in the workplace and because discrimination against men is linked to discrimination against women.

The total number of Supreme Court cases analyzed is 21. Included in the analysis are both majority and concurring opinions and dissents. Content analysis is used to analyze systematically the construction of ideas about gender discrimination. I use a method adapted from William Gamson and Andre Modigliani (1989), who set forth a constructionist approach for analyzing the public discourse in a study they conducted on the media and nuclear power. They analyze the various ways that positions were communicated on this issue through "interpretative packages" or "frames" that set forth the story line and gave meaning to it. According to Gamson and Modigliani, each package contains an "or- 
ganizing idea" and "signature elements," or symbols, which act as a convenient shorthand for describing the problem (see also Best 1995 and Burstein et al. 1995 for a similar approach).

A review of the feminist and legal scholarly literature indicates three dominant frames in the area of gender discrimination: separate spheres, equality, and difference theory. Content analysis is used to determine to what extent the Court relied on these frames, modified, or deviated from them. The study analyzes the images of men and women that were used by the Court to support its reliance on a particular frame. ${ }^{6}$ The Court's statements on cultural norms and understandings are also analyzed.

The first frame, separate spheres, encompasses the idea that women and men are different and, hence, should be treated differently (Cook 1978). Each occupies a different sphere of life. The men's sphere is "the impersonal, public and competitive"; the women's, the "personal, private, and charitable" (Matthaei 1982, p. 117). This frame casts biology as destiny, relegating women to the maternal role and making them less than men, both physically and mentally. It is this frame that has historically dominated legal (and social and cultural) thought (Williams 1992). It is reflected in such early Supreme Court decisions as Bradwell and Muller v. Oregon (208 U.S. 412 [1908]), which upheld restrictions on the number of hours a woman could work because "her physical structure and the performance of maternal functions place her at a disadvantage in the struggle for subsistence" (p. 421).

The second frame, equality, was formulated in direct response to the first. This frame emphasizes the "right of each individual to equal treatment based on equal performance" (Freedman 1983, p. 913; see also Williams 1984, 1992; Kirp, Yudof, and Franks 1986; Bartlett 1993). The similarities between men and women, rather than differences (biological or otherwise), are emphasized. This concept of equality had its genesis in the civil rights movement (Kay 1985). Just as blacks "face no natural handicaps and possess no natural significant differences than whites" (Littleton 1987, p. 1289), there are "no significant natural differences between men and women" (Littleton 1987, p. 1291). Perceived differences are in fact overbroad generalizations and stereotypes that are not applicable to individual women. Under this concept of equality, there may be some instances where women may be treated differently in order to make up for past discrimination, but only temporarily. Pregnancy, the one obvious and inescapable difference between men and women, is viewed as similar to disabilities that may from time to time affect men and women alike (Williams 1984). This conception of equality emphasizes the sameness of men and women, limiting focus on any special accommodations for gender-related conditions because of the frequency with which such distinctions had been used against women in the past (Williams 1984). 
The third frame, difference theory, was formulated by feminist scholars who view the equality framework as too often requiring women to fit into the norms of the male world (Gilligan 1982; Law 1984; Littleton 1987; Pruitt 1994). According to these feminists, equality theory does not sufficiently take into account biological differences, such as pregnancy, social norms, and social practices, which have disadvantaged women in the past. Difference theory recognizes biological and culturally influenced differences but does not view them as the separate spheres frame does. Women are not to be punished or protected based on these differences, but neither should they be treated the same as men (Littleton 1987). Rather, women should be compensated when a cultural or biological difference has unequal and negative consequences (Littleton 1987). They should get either special rights based on their special needs or accommodations that eliminate any advantage for men (Law 1984). For example, pregnant women should be entitled to workrelated disability benefits, not because pregnancy is similar to other disabilities, but because it is a burden that falls unequally on women (Littleton 1987). Those in gender-segregated occupations, such as nursing and teaching, should be entitled to higher compensation, not because their jobs are necessarily equivalent to men's, but because their low pay is a reflection of the lower esteem in which so-called female occupations are held in society.

\section{Discussion and Findings}

The Supreme Court decided 21 cases involving 23 issues that relate to gender discrimination in employment between 1971 and 1982. Most of the cases were brought against governmental agencies that administered various benefit programs (e.g., Social Security or unemployment insurance benefits) or that ran entities such as schools or prisons. Only five cases were brought against private employers.

The cases fall into the following three categories: challenges to benefit programs, pay scales, and promotion and seniority rules; pregnancyand maternity-related issues in the workplace; and gender-related exclusions from employment or professional schools. Of the 23 practices challenged as discriminatory, 16 were invalidated and seven upheld. Eight of the cases were brought by men claiming discrimination. In all but three of these cases, the men were successful.

An analysis of the voting records of each justice reveals distinct patterns (see table 1). Some justices routinely voted for outcomes that advanced the cause of women's rights, while others did not. ${ }^{7}$ The greatest disparity is between Justice Marshall and Justice Rehnquist. Justice Marshall voted the profeminist position in 22 out of 23 cases. (His single antifeminist vote was based on the premise that the legislature had already taken care of the discriminatory practice.) Justice Rehnquist 


\section{Social Service Review}

Table 1

Supreme Court Cases on Gender Discrimination in Employment (1971-82): Justices' VOTES

\begin{tabular}{|c|c|c|c|c|c|c|c|c|c|c|c|}
\hline Case & DUG & POW & BRN & WHT & MAR & BRG & RHN & BLM & STW & STV & Vote \\
\hline Phillips & + & & + & + & + & + & & + & + & & $9-0$ \\
\hline Frontiero & + & + & + & + & + & + & - & + & + & & $8-1$ \\
\hline LaFleur & + & + & + & + & + & - & - & + & + & & $7-2$ \\
\hline Brennan & + & + & + & + & + & - & - & - & 0 & & $5-3$ \\
\hline Aiello & + & - & + & - & + & - & - & - & - & & $6-3$ \\
\hline Ballard & - & + & - & - & - & + & + & + & + & & $5-4$ \\
\hline Wiesenfeld & 0 & + & + & + & + & + & + & + & + & & $8-0$ \\
\hline Turner & + & + & + & + & + & 0 & - & 0 & + & & $6-3$ \\
\hline Gilbert & & - & + & - & + & - & - & - & - & + & $6-3$ \\
\hline Goldfarb & & + & + & + & + & - & - & - & - & + & $5-4$ \\
\hline Webster & & + & + & + & + & + & + & + & + & + & $9-0$ \\
\hline Satty (1) & & + & + & + & + & + & + & + & + & + & $9-0$ \\
\hline Satty (2) & & + & + & - & + & - & - & - & - & - & $6-3$ \\
\hline Dothard (1) & & + & + & - & + & + & + & + & + & + & $8-1$ \\
\hline Dothard (2) & & - & + & - & + & - & - & - & - & - & $6-3$ \\
\hline Manhart & & + & 0 & + & + & - & - & + & + & + & $6-2$ \\
\hline Feeney & & - & + & - & + & - & - & - & - & - & $7-2$ \\
\hline Westcott & & + & + & + & + & + & + & + & + & + & $9-\overline{0}$ \\
\hline Wengler & & + & + & + & + & + & - & + & + & + & $8-1$ \\
\hline Gunther & & - & + & + & + & - & - & + & - & + & $5-4$ \\
\hline Rostker & & - & + & + & + & - & - & - & - & - & $6-3$ \\
\hline Ford & & - & + & - & + & - & - & + & & - & $6-3$ \\
\hline Hogan & & - & + & + & + & - & - & - & & + & $5-4$ \\
\hline$\%$ Profeminist & 85 & 63 & 95 & 65 & 95 & 40 & 27 & 59 & 60 & 66 & \\
\hline
\end{tabular}

Note. $-+=$ profeminist; $-=$ antifeminist; $0=$ no participation in vote. Symbols based on a modified version of a scalogram used by Cook (1978). DUG = William Douglas; POW = Lewis Powell; BRN = William Brennan; WHT = Byron White; MAR = Thurgood Marshall; BRG = Warren Burger; RHN = William Rehnquist; BLM = Harry Blackmun; $\mathrm{STW}=$ Potter Stewart; STV = John Paul Stevens.

voted the profeminist position in only 27 percent of cases. Chief Justice Burger has the next lowest rating, at 40 percent. The remaining justices, with the exception of Douglas, who voted profeminist 85 percent of the time, are in the 59-65 percent range.

Based on outcomes only, this was a Court that in the aggregate could be fairly characterized as supportive of women's rights in the employment context. It was also a Court characterized, for the most part, by consensus (see table 1). Only four out of the 23 decisions were decided by a 5-4 margin. Eight decisions were unanimous or had only one dissenting vote. The most frequent voting split was $6-3$. However, a textual analysis of the decisions reveals much more complex, nuanced views on gender discrimination and concepts of equality (see table 2 for a summary of the results as explained below). 
Table 2

Supreme Court Cases on Gender Discrimination in Employment (1971-82)

\begin{tabular}{|c|c|c|c|c|}
\hline Case & Issue & Date & Vote & Frame \\
\hline Phillips & $\begin{array}{l}\text { Mothers of preschool children denied } \\
\text { employment }\end{array}$ & 1971 & + & $\mathrm{E}$ \\
\hline Frontiero & $\begin{array}{l}\text { Spouses of female, but not male, soldiers } \\
\text { must show need for benefits }\end{array}$ & 1973 & + & $\mathrm{E}$ \\
\hline LaFleur & Forced maternity leave in school system & 1974 & + & $\mathrm{E}$ \\
\hline Brennan & $\begin{array}{l}\text { Pay scale differential evening/day shift } \\
\text { benefited men }\end{array}$ & 1974 & + & D \\
\hline Aiello & $\begin{array}{l}\text { Pregnancy excluded from coverage in } \\
\text { state disability benefits program }\end{array}$ & 1974 & - & $\mathrm{S}$ \\
\hline Ballard & $\begin{array}{l}\text { Military promotions for women less strin- } \\
\text { gent than for men }\end{array}$ & 1975 & + & $\mathrm{E}$ \\
\hline Wiesenfeld & $\begin{array}{l}\text { Social Security mother's benefits denied } \\
\text { to men }\end{array}$ & 1975 & + & $\mathrm{E}$ \\
\hline Turner & $\begin{array}{l}\text { Unemployment benefits for pregnant } \\
\text { women denied }\end{array}$ & 1975 & + & $\mathrm{E}$ \\
\hline Gilbert & $\begin{array}{l}\text { Pregnancy excluded from coverage in pri- } \\
\text { vate disability benefits program }\end{array}$ & 1976 & - & S \\
\hline Goldfarb & $\begin{array}{l}\text { Widowers, not widows, must show need } \\
\text { for Social Security widow benefits }\end{array}$ & 1977 & + & $\mathrm{E}$ \\
\hline Webster & $\begin{array}{l}\text { Social Security earnings calculations more } \\
\text { advantageous for women }\end{array}$ & 1977 & + & $\mathrm{E}$ \\
\hline Satty & $\begin{array}{l}\text { 1) Seniority lost upon return from mater- } \\
\text { nity leave }\end{array}$ & 1977 & + & D \\
\hline Satty & $\begin{array}{l}\text { 2) Sick leave cannot be used for mater- } \\
\text { nity leave }\end{array}$ & 1977 & - & $\mathrm{S}$ \\
\hline Dothard & $\begin{array}{l}\text { 1) Height/weight requirements for cor- } \\
\text { rections officers eliminated women }\end{array}$ & 1977 & + & $\mathrm{E}$ \\
\hline Dothard & $\begin{array}{l}\text { 2) Contact positions in all male prisons } \\
\text { denied to women }\end{array}$ & 1977 & + & $\mathrm{S}$ \\
\hline Manhart & Pension contributions higher for women & 1978 & + & $\mathrm{E}$ \\
\hline Feeney & $\begin{array}{l}\text { Veterans' preference programs excluded } \\
\text { women from government jobs }\end{array}$ & 1979 & - & $\mathrm{S}$ \\
\hline Westcott & AFDC-UF program restricted to men & 1979 & + & $\mathrm{E}$ \\
\hline Wengler & $\begin{array}{l}\text { Widowers, not widows, must show need } \\
\text { for workmen's compensation benefits }\end{array}$ & 1980 & + & $\mathrm{E}$ \\
\hline Gunther & $\begin{array}{l}\text { Pay scale for guards in prison system } \\
\text { lower for women }\end{array}$ & 1981 & + & D \\
\hline Rostker & Registration of women for the draft & 1981 & - & $\mathrm{S}$ \\
\hline Ford & $\begin{array}{l}\text { Retroactive seniority denied to successful } \\
\text { Title VII claimants }\end{array}$ & 1982 & - & $\mathrm{S}$ \\
\hline Hogan & State nursing school restricted to women & 1982 & + & $\mathrm{E}$ \\
\hline
\end{tabular}

Note. $-+=$ profeminist $--=$ antifeminist; $\mathrm{S}=$ separate spheres; $\mathrm{E}=$ equality; $\mathrm{D}=$ difference theory; AFDC-UF = Aid to Families with Dependent Children-Unemployed Father. 
Equalizing Benefits and Pay Scales

Slightly less than half ( 47 percent) of the issues brought before the Court involved work-related benefits, pay scales, and rules regarding seniority and promotion (referred to collectively as the "benefits cases"). Three cases addressed programs that made it more difficult for men to receive benefits by requiring them, and not women, to show need; these programs included state workmen's compensation (Wengler $v$. Druggists Mutual Insurance 1980), Social Security (Weinberger v. Wiesenfeld 1975), and military benefit programs (Frontiero v. Richardson 1973). Thus, for example, the spouse of a male soldier was entitled to medical and dental benefits and an increased housing allowance, but spouses of female soldiers had to show that they were dependent on their wives. Likewise, widows were automatically entitled to Social Security widow's benefits and workmen's compensation benefits upon the death of their spouses, but men had to demonstrate that their wives had supported them.

Some benefits were available to only one sex. For example, Social Security mother's benefits were available to mothers with young children whose father had died but not to fathers when the mother died (Califano v. Goldfarb 1977). Men were entitled to benefits under the Aid to Families with Dependent Children-Unemployed Father (AFDC-UF) program, but women were not (Califano $v$. Westcott 1979). In other instances, the amount of benefits varied according to gender. For example, women were able to calculate their Social Security benefits differently, and more liberally, than men (Califano v. Webster 1977). In another case women were required to contribute more to an employer pension plan than men (City of Los Angeles v. Manhart 1978).

The remaining cases in this category involved unequal pay scales between men and women (Corning Glass Works v. Brennan 1974; County of Washington v. Gunther 1981), promotional requirements that were more stringent for male soldiers than for female soldiers (Schlesinger $v$. Ballard 1975), and an employer's seniority policy regarding women who had successfully filed discrimination complaints (Ford Motor Co. v. EEOC 1982).

The cases were, with one exception discussed below, resolved by invalidating the practices as discriminatory. The Court primarily relied on the equality frame, constructing a notion of equality that emphasizes the similarities between men and women, as well as the desirability of affording the same treatment to each.

To construct this narrative of equality, the Court recast traditional images of women as primarily mothers and men as breadwinners. Thus, in Brennan, when mostly male night shift inspectors were paid more than female day shift inspectors for the same work, the Court (citing a Senate Report) rejected the "ancient and outmoded belief that a man 
because of his role in society should be paid more" and invalidated the pay scale (p. 195).

Likewise, benefit programs that had originally been enacted as protective programs for women, such as mother's benefits, were redefined along with women's and men's roles. Images of the stereotypical homemaker, who relied on her husband's earnings and was in dire need if her husband died, were replaced by those of the working woman, who was discriminated against because her family did not receive the same benefits as those of working men if she died. As the Court put it, "the presumption of complete dependency of wives upon husbands has little relationship to present reality" (Wiesenfeld, p. 643). Conversely, men were depicted as caretakers who, if their spouse died, might like the option to remain at home, caring for their children. Fathers, no less than mothers, have the right to the "companionship, care, custody and management of their children" (p. 652). In this way, the Court constructed a more egalitarian view of the respective roles and relationships of men and women in society. This markedly deviated from the bifurcated and traditional view of men as breadwinners and women as homemakers. ${ }^{8}$

In fashioning its concept of equality in the benefits cases, the Court demonstrated a certain degree of elasticity, particularly when it was not so easy to mute the differences between men and women by simply revising cultural roles. For example, the issue in Manhart involved a pension plan to which women were required to contribute more than men because they tend to live longer and, hence, as a group receive more benefits than men. Here the Court formulated a more nuanced and individualized version of equality. It invalidated the practice because each individual woman may not in fact live as long as the statistical woman. Thus, equality was not only about treating similarly situated groups the same but also about eschewing group generalizations (even empirically based ones) and treating people as individuals who are equally entitled to certain benefits.

The Court also adopted the compensatory aspect of the equality frame, which recognizes that treating men and women the same does not always ensure equality, especially where women suffer from a disadvantage. Thus, the Court acknowledged in several cases that equal treatment can lead to unequal outcomes because men and women do not always start from the same place. The Court's clearest statement of this came in a challenge to a Social Security regulation that allowed women more flexibility than men in choosing which earning years prior to 1972 to include when calculating benefits (Webster). In upholding the regulation, which sometimes resulted in higher benefits for women than men who were born during the same years, the Court underscored the need for this flexibility because "whether from overt discrimination or from the socialization process of a male dominated culture, the job market is inhospitable to the woman seeking any but the lowest paying 
job" (p. 318). Likewise, in Ballard, the Court recognized the pernicious effects of discrimination in the military, allowing women more time than men to obtain a promotion before being forcibly discharged for not obtaining one.

In Gunther, a pay scale case, the Court took the next steps in the evolutions of feminist and applied difference theories. The plaintiffs in Gunther were female prison guards who were paid less than male counterparts. Under the Equal Pay Act, women were to receive equal pay for equal work. However, because the male and female guards did not perform equivalent work (men guarded more prisoners while women did more clerical work), the equal pay for equal work formula was of no help. The female guards argued that Title VII (Title VII of the Civil Rights Act of 1964, U.S. Public Law 88-352, 78 Stat. 241, codified at 42 U.S.C. 2000e) could be interpreted more broadly than the equal pay for equal work standard contained in the Equal Pay Act.

The Court upheld this expansive interpretation of Title VII and allowed women to bring claims for discrimination even where they were doing jobs that were not equivalent to men's. As the majority in Gunther noted, the equal pay for equal work formula was of no help to women in sex-segregated occupations where there were few if any men performing the same work. This would limit Title VII remedies to only those professions, such as accounting and law, where men could be found, thus leaving the majority of women without protection. ${ }^{9}$

Using the difference theory frame, the Court explicitly acknowledged that culture-based differences result in women's jobs being less valued than men's jobs and that the equality remedy, equal pay for equal work, does not provide a solution. In so doing, the Court went beyond the equality remedies in Gunther and Webster that were time limited or designed to remedy specific acts of past discrimination. Consistent with difference theory, it allowed women to use Title VII in a way that would compensate them for the negative consequences that fall on women as a result of culturally and socially created differences. ${ }^{10}$

The one unsuccessful case in the category of work-related benefits involved remedies for discrimination. In Ford, after Ford Motor Company was found in violation of Title VII by refusing to hire women for certain jobs, the company offered the women jobs but without retroactive seniority. Since seniority was the key to a whole host of benefits, including wage levels, promotions, transfers, and protection from layoffs, this put women at a distinct disadvantage, especially in relation to those men who had been hired at the same time the women had been illegally refused jobs.

Based on the equality frame it had developed in earlier cases, the Court could have determined that because women did not start at the same place as men, particularly at Ford, they should be fully compensated, which only retroactive seniority would do. Instead, the Court 
opted to protect the men rather than compensate the women. As the Court explained, to do otherwise would result in labor unrest, low morale, and harm to innocent third parties by disrupting the established seniority hierarchy. Perhaps the presence of a distinct and identifiable group of men that would be harmed stopped the Court from applying the equality frame. The decision presages arguments made in later years by opponents of affirmative action that so-called reverse discrimination could also be a violation of equality.

As noted above, this was the only instance in this category of cases when an allegedly discriminatory practice was upheld by the Court. In the relatively straightforward area of work-related benefits, the Court reached a consensus that men and women are equally entitled to such benefits and that, at least in some instances, compensatory and differential treatment of women is necessary in order to redress past discrimination.

Such a consensus did not always mean that the justices had identical beliefs on equality or similar views of men's and women's roles, as evidenced by some of the differences between majority and concurring opinions. Not all of the profeminist justices shared the view that men's and women's social roles are interchangeable. The concurring justices in Wiesenfeld reinforced traditional gender roles by commenting that they did not think fathers would ultimately end up staying home, even if granted mother's benefits. And a concurring justice in Wengler and Goldfarb, in contrast to the majority opinion, viewed a man's inability to collect benefits based on his wife's work record as discrimination against men, not women. This, in effect, minimized the majorities' emphasis on women as workers whose families were entitled to the same benefits as those of working men.

Dissenting justices spoke sparsely on the issue of equality, choosing either to attack the majority's decisions on more technical grounds or not to respond with full dissents. However, when they did directly address the issue, consistent with the separate spheres frame, it was to emphasize the differences between men and women and, hence, the appropriateness of having different standards. Difference was emphasized not, as in difference theory, to compensate women for the unequal consequences of such differences, but to justify different treatment of the sexes. Thus, because women tend to live longer than men, they could be required to pay more into a pension plan. Similarly, as the dissent argued in Goldfarb, because statistics showed that women, and not men, were more likely to be dependent on a spouse, it was appropriate to require men, and not women, to show that they had been supported by their spouse in order to be eligible for widow's benefits.

Goldfarb also demonstrated the differing and selective use of statistics by both the majority and dissent to support their respective views. The majority marshaled statistics to show the number of working women, thus emphasizing facts that made women more like men (both worked). 
The dissent called on a different set of statistics to show that women were more likely to be dependent on their husbands than vice versa, thus emphasizing how women and men were different. The similarity of men and women proved even more contentious when the justices addressed workplace issues relating to pregnancy and child rearing.

\section{Pregnancy and Mothering}

The most defining difference between men and women, reproductive capability, came before the Court frequently in this era. Of the 23 issues that the Court decided, five involved pregnancy and one directly related to a woman's role as a mother. These cases included the exclusion of pregnant women from unemployment programs (Turner v. Utah 1975) and state and private disability benefit programs (Geduldig v. Aiello 1974; General Electric v. Gilbert 1976), forced maternity leaves (Cleveland Board of Education $v$. LaFleur 1974), and the loss of seniority and sick leave during maternity leaves (Nashville Gas Co. v. Satty 1977). An employer's refusal to hire women with preschool-age children was also challenged (Phillips v. Martin Marietta Corp. 1971).

The outcomes of these cases were not as uniform and consistent as those of the benefits cases. According to the Court, forced maternity leave, the denial of unemployment benefits, and the loss of seniority were wrong. Denying pregnant women disability benefits and pregnancyrelated sick leave were right. In one case, the Court observed that pregnancy "imposed on women a substantial burden that men need not suffer" (Satty, p. 141), while in another case it said "pregnancy [was not] a sex-based classification" (Gilbert, p. 134). In Phillips, the Court held that male and female parents must be judged by the same standard, but conflicting family obligations may be more relevant to job performance for women than men. Thus, in contrast to the benefits cases, it is clear that pregnancy and child rearing were conundrums the Court could not easily resolve. ${ }^{11}$

Perhaps the simplest pregnancy issue was that posed by LaFleur, where schoolteachers were forced to go on maternity leave in their fourth month of pregnancy, regardless of their physical condition. The equality framework worked well here, especially the variation that emphasizes the individual over group generalizations. The LaFleur Court emphasized the unique way in which each woman experienced pregnancy, constructing it as primarily an individual issue not amenable to rigid rules, such as a forced maternity leave date, which applied detrimentally to all women. By criticizing the school board for having an archaic attitude toward pregnant women working after pregnancy became visible, the Court's decision also attacked taboos against pregnant women working.

The Court also relied on the equality frame when a state denied 
pregnant women unemployment benefits and thereby deemed them unavailable for employment. Echoing the language of LaFleur, it pointed out that not all pregnant women were unable to work when pregnant, thus making the blanket denial of unemployment benefits wrong.

The Court drew on difference theory when, in Satty, women challenged their loss of seniority upon returning from maternity leave. In clearly worded difference theory language, the Court noted that pregnancy "imposed on women a substantial burden that men need not suffer" because "of their differing roles in the scheme of human existence" (Satty, p. 142). The Court directly linked the effect of women's different role and employment opportunities, emphasizing how difficult it would be for women to advance if they lost seniority every time they took maternity leave. Recognizing a biological difference that had unequal and negative consequences for women, the Court ordered a remedy (restoration of seniority) that fit squarely into the framework of difference theory. ${ }^{12}$

However, the Court reversed course when it came to disability benefits and sick leave, also holding in Satty that women cannot use their sick pay while on maternity leave and in Aiello and Gilbert that women could be denied disability benefits for pregnancy, even while men were able to collect for disabilities that affected only them (e.g., prostate disease). The Court rejected the equality argument that analogizes pregnancy to other disabilities because the consequences, the inability to work, are the same. The Court also rejected the idea that because only women became pregnant, the denial of pregnancy disability benefits was a gender-based classification. ${ }^{13}$

According to the Court, the distinction was not between women and men, but between pregnant and nonpregnant individuals (including women). Pregnancy was considered by the Court as an additional risk, unique to women. As one noted feminist scholar, Wendy Williams, commented about the case, this reasoning made men the standard in the workplace (1984). Since pregnancy is an "extra," a unique condition not analogous to anything men experience, its impact on women in the workplace does not have to be considered. Only when women are like men will they be treated the same. When pregnancy makes women different, economic penalties inure to them (no disability coverage) that do not apply to disabled male workers (even those suffering from gender-related disabilities). In other words, when women enter the so-called separate sphere of pregnancy, they need not be accommodated in the workplace, no matter the work-related consequences. ${ }^{14}$

The pregnancy disability cases put the Court out of sync with Congress. ${ }^{15}$ Congress viewed pregnancy disability benefits as an issue of formal equality, as did the dissenting justices in Aiello and Gilbert. It passed the Pregnancy Discrimination Act in 1978, which, using classic equality 
language, mandated that women "affected by childbirth and related conditions . . . be treated the same as other persons not so affected but similar in their ability or inability to work." It was the only time during this era when one of the Court's decisions in the area of gender discrimination was reversed through legislation.

\section{Barriers to Employment}

Cases under this category include a challenge to a prison system that refused to hire women as corrections officers (Dothard $v$. Rawlinson 1977) and a veterans preference program in state government that resulted in the exclusion of women from virtually all of the professional slots (Personnel Administrator of Massachusetts v. Feeney 1979). Men challenged women's exclusion from the draft (Rostker v. Goldberg 1981) and their own exclusion from a state nursing school (Mississippi University for Women v. Hogan 1982).

Hogan, like several of the benefits cases, was brought by a man who was excluded from a state university nursing program. Like the benefits cases, the decision relied on the equality frame. The Court, however, focused primarily on the harm to women, not men. According to the Court, excluding men perpetuated stereotypes that nursing was a female profession. $^{16}$

In Dothard, the Court found it difficult to hew to one standard frame as it veered from an equality frame to a separate spheres frame when deciding what role women could play in prisons. When confronted with a challenge to height and weight requirements that eliminated most women for employment as corrections officers, the Court used an equality frame. The Court severed the connection between size and strength, the relevant component to job performance as a corrections officer, and invalidated the requirement.

But in the same case, the Court rejected the women's claim that they should also be permitted to serve as prison guards in certain all-male prisons. In the Court's most overt statement of the separate spheres theme during this era, the justices invoked the traditional image of women as seductive sexual objects. It constructed a picture of women preyed upon by inmates deprived of heterosexual sex, with "a woman's relative ability to maintain order in a male, maximum security prison . . . directly reduced by her womanhood" (Dothard, p. 335). ${ }^{17}$ Thus, this one case contained two very different images of a woman: one where she could compete equally with men, even in traditionally male occupations, such as law enforcement, requiring physical characteristics as part of the selection criteria and a contrary image where she was completely defined by her own sexuality, unable even to make her own employment choices.

The Court addressed women's role in another traditionally all-male 
sphere: the military. During the 1970s, barriers to women's participation in the military were falling. The president, the Defense Department, and all of the chiefs of the armed forces supported drafting women (although not for combat positions). Congress opposed it. The Court resolved the issue by siding with Congress. The Court reasoned that since women were excluded from combat, they were not similarly situated to men, and hence there was no need to include them in the draft. The Court framed women's exclusion from combat as a widely accepted cultural precept, citing a Senate report stating "the principle that women should not intentionally and routinely engage in combat is fundamental, and enjoys wide support among our people" (Rostker, p. 77).

It was a cultural precept shared by the dissenting justices. While chastising the majority for stereotyping women, who had an important role to play in the military and should be drafted, they agreed that excluding women from combat was appropriate. Rostker, then, reinforced the notion that, equality notwithstanding, women could still not do everything men could do and, at least for some things, still existed in a separate sphere.

In another case directed to service in the military, specifically veterans' preference programs in state government, the Court also relied on the separate spheres frame, albeit in a less direct way. In Feeney, at issue was the Massachusetts veterans' preference program, which was especially broad even for its time. While other civil service preference systems rewarded veterans points, Massachusetts gave an absolute preference (Kerber 1998). Thus women who scored among the top on civil service tests were routinely and repeatedly passed over for the higher-status positions in favor of veterans. Only the lower-level positions that traditionally fell to women were exempt from the veterans' preference. This resulted in a two-tiered workforce in state government, with men occupying higher-status jobs, such as attorneys and accountants, and women refining the lower-status jobs, such as clerk and secretary, that traditionally employed women.

The Court upheld the law without overtly relying on a separate sphere frame; in fact, it said the preferences had nothing to do with women at all. According to the Court, the law was merely providing opportunities to veterans, not excluding women. Similar to the pregnancy disability cases, where the distinction was between pregnant women and nonpregnant people, the difference was not between men and women, but between veterans and nonveterans (a category that included a substantial number of men).

The underlying theme of separate spheres became more apparent when the Court acknowledged that discrimination against women in the military meant that there were fewer female veterans but that this fact was irrelevant to Massachusetts's preference program. Thus, as in 
the pregnancy disability cases, the Court refused to acknowledge a gender-related link that had a disproportionate and harmful impact on women in the workplace. In short, pursuing a policy that overwhelmingly benefited men, it chose to ignore the impact on women, thus making women less important in the public sphere of work. The harm to women was recognized by the dissenting justices who saw the preference program as purposeful discrimination, reflecting and perpetuating "archaic assumptions about women's roles" and creating a gender-based civil service hierarchy that could have easily been foreseen (Feeney, p. 891).

\section{Conclusion}

The Court actively participated, as did Congress and the executive branch, in the public discourse on gender discrimination throughout the 1970s. During this decade, the pace of legislation and court decisions increased as the various government institutions grappled with the issues presented by the women's movement. The Court's explicit task was to decide, often in cases of first impression, what legal standard under the Constitution it should apply to women and to interpret federal laws such as the Equal Pay Act and Title VII of the Civil Rights Act of 1964. For legal scholars, the central legal question of the decade was the formulation of a legal standard for gender discrimination cases, specifically, whether the Court was going to apply strict scrutiny or the rational basis standard to gender discrimination claims. ${ }^{18}$

The Courts answered in Craig v. Boren (429 U.S. 190 [1976]) by deciding that gender-related laws would be subject to "intermediate scrutiny," which means that the law in question must serve an important governmental objective and be substantially related to achievement of those objectives (Nowak and Rotunda 1995). This article describes the subtext running beneath this and other legal rules articulated by the Court. It shows what the justices thought about equality, the roles of men and women, and the outer limits of change, as they addressed a host of issues, including benefits, hiring practices, and the consequences of pregnancy and motherhood in the workplace.

Oscillating between separate spheres, equality, and differences theory frames, the Court helped redraw the cultural lines. It pushed that line forward when, particularly in the benefits cases, it used the principles of equality to redefine the workplace to include working women as a norm, entitled to be treated as equal to men and to be compensated for past discrimination.

This theme echoed the definition of equality used by feminists in the early years of the movement, including now Justice Ginsberg, who brought the first discrimination cases to the Court (Williams 1984; Abrams 1997). The Court's focus on individual characteristics, rather 
than group generalizations when formulating its concept of equality (e.g., in the maternity leave, pension, and unemployment benefits cases), echoed larger cultural themes that focus on the protection and enhancement of individual rights as a basic form of democracy.

When equality proved to have its limits, the Court even ventured into difference theory, a concept of equality that was viewed by feminist scholars as the next and necessary step. To be sure, the Court's use of this theory was tepid; it applied it in only two cases. But that it appeared at all is one indication of how nuanced and flexible the justices' discourse could be as they, along with others in the political arena, struggled to define and respond to gender discrimination.

At the same time, the Court also displayed a hesitancy to push the cultural line too far forward. The hard cases at either end of the equality spectrum, when women asked to enter the roughest domains of men (male prisons and the draft) or asked that their most "womanly" characteristic, pregnancy, be accommodated, proved difficult for the Court. Here the Court's reasoning was less consistent and clear. In the pregnancy disability cases, it proved to be out of step with that of the rest of the country. ${ }^{19}$

However, even the separate sphere cases are notable for the absence of the more overt gender stereotyping that would have characterized such decisions in the past (with the exception of Dothard and, to a lesser extent, Rostker). Indeed, the Court appeared to go out of its way in the pregnancy disability and veterans' preference cases to state that it was not treating women differently than men. This led to some convoluted reasoning, for example, when the Court insisted that even though only women get pregnant, pregnancy is not a sex-based classification. However, it is notable that the Court avoids stereotyping the separate spheres, for the most part. This is an indication of how much the Court both absorbed and reflected current contemporary mores about gender discrimination and the role of women, even as it sometimes relegated women to a separate sphere.

The approach used here to understand the Court can be applied whenever reading Supreme Court decisions. For example, the 1986 decision in Meritor Savings Bank, F.S.B. v. Vinson (106 S.Ct. 2399) represented a new variation in the Court's definition of equality. In that case, the Court recognized sexual harassment as a form of sexual discrimination, framing the issue as one involving the imbalance of power between men and women. ${ }^{20}$ This went beyond the previous formulations of equality and difference theory that are described above. Another very recent example is Nguyen v. INS (121 S.Ct. 2053), decided in 2001, involving a federal law that made it easier for a mother than a father to establish American citizenship for a child born abroad out of wedlock. In upholding the regulation, the Court relied on its own ideas of men's and women's respective parenting roles. The language of its decision 
reinforced traditional notions of motherhood and stereotypes of fathers as less likely to develop caring relationships with their children. This decision can be read as a sign that traditional images of women continue to play a role in the public discourse.

In sum, because of the Supreme Court's policy-making role, it is as important to unravel the moral, social, and political values embedded in its decisions as it is to understand the Court's legal pronouncements. Such a focus can help reveal the often unresolved ideological tensions and inconsistencies underlying our public debates, while also suggesting future areas of controversy. As past and more recent Court decisions indicate, the equality debate is not over; it is not clear whether we are moving toward a gender-blind society or a more subtle accommodation of men's and women's differences. One task of those engaged in the public discourse is to respond to competing definitions of a social problem offered by various actors on the public stage. Reading between the lines of Supreme Court decisions is a way of mapping out the political, social, and cultural terrain so that social workers and others engaged in the policy-making process can fully and effectively engage in the public discourse.

\section{Appendix}

Index of Cases (1971-82)

Califano v. Goldfarb, 430 U.S. 199 (1977)

Califano v. Webster, 430 U.S. 313 (1977)

Califano v. Westcott, 443 U.S. 76 (1979)

City of Los Angeles v. Manhart, 435 U.S. 702 (1978)

Cleveland v. LaFleur, 414 U.S. 632 (1974)

Corning Glass Works v. Brennan, 417 U.S. 188 (1974)

County of Washington v. Gunther, 452 U.S. 161 (1981)

Dothard V. Rawlinson, 433 U.S. 321 (1977)

Ford Motor Co. v. EEOC, 458 U.S. 219 (1982)

Frontiero v. Richardson, 411 U.S. 677 (1973)

Geduldig v. Aiello, 417 U.S. 484 (1974)

General Electric v. Gilbert, 429 U.S. 125 (1976)

Mississippi University for Women v. Hogan, 458 U.S. 718 (1982)

Nashville Gas Co. v. Satty, 434 U.S. 136 (1977)

Personnel Administrator of Massachusetts v. Feeney, 442 U.S. 256 (1979)

Phillips v. Martin Marietta Corp., 400 U.S. 542 (1971)

Rostker v. Goldberg, 453 U.S. 57 (1981)

Schlesinger v. Ballard, 419 U.S. 498 (1975)

Turner v. Utah, 423 U.S. 44 (1975)

Weinberger v. Wiesenfeld, 420 U.S. 636 (1975)

Wengler v. Druggists Mutual Insurance, 446 U.S. 142 (1980) 


\section{References}

Abrams, Kathryn. 1997. "The Constitution of Women." Alabama Law Review 48 (3): 861-84. Bartlett, Katharine. 1993. Gender and the Law: Theory, Doctrine, and Commentary. New York: Little Brown.

Berger, Peter, and Thomas Luckman. 1966. The Social Construction of Reality. Garden City, N.Y.: Doubleday.

Best, Joel. 1995. Images of Issues. Hawthorne, N.Y.: Aldine de Gruyter.

Boneparth, Ellen, ed. 1982. Women, Power and Policy. New York: Pergamon.

$\rightarrow$ Burstein, Paul. 1991. "Legal Mobilization as a Social Movement Tactic: The Struggle for Equal Employment Opportunity." American Journal of Sociology 96 (5): 1201-25.

$\rightarrow$ Burstein, Paul, Marie Bricher, and Rachel Einwohner. 1995. "Policy Alternatives and Political Change: Work, Family and Gender on the Congressional Agenda." American Sociological Review 60 (1): 67-83.

$\rightarrow$ Casper, Jonathon. 1976. "The Supreme Court and National Policy Making." American Political Science Review 70 (1): 50-63.

Cook, Beverly. 1978. "The Burger Court and Women's Rights 1971-1977.” Pp. 47-83 in Women in the Courts, edited by Winifred Hepperle and Laura Crites. Williamsburg, Va.: National Center for State Courts.

Cross, Frank, and Emerson Tiller. 2000. "The Three Faces of Federalism: An Empirical Assessment of Supreme Court Federalism Jurisprudence." Southern California Law Review 73 (4): 741-71.

Dahl, Robert. 1957. "Decision Making in a Democracy: The Supreme Court as a National Policymaker." Journal of Public Law 6:279-95.

$\rightarrow$ de Goede, Marieke. 1996. "Ideology in the U.S. Welfare Debate." Discourse and Society 7 (3): $317-57$.

$\rightarrow$ Eskridge, William. 1991. "Civil Rights Legislation in the 1990s: Reneging on History? Playing the Court/Congress/President Civil Rights Game." California Law Review 79 (3): 613-84.

Ferree, Myra Marx, and Beth Hess. 2000. Controversy and Coalition: The New Feminist Movement across Four Decades of Change. New York: Routledge.

Frank, Jerome. 1949. Law and the Modern Mind. New York: Coward-McCann.

$\rightarrow$ Freedman, Ann E. 1983. "Sex Equality, Sex Differences, and the Supreme Court." Yale Law Journal 92 (6): 913-68.

Freeman, Jo. 1982. "Women and Public Policy: An Overview." Pp. 47-67 in Boneparth, ed.

— 1990. "From Protection to Equal Opportunity: The Revolution in Women's Legal Status." Pp. 456-81 in Women, Politics, and Change, edited by Louise A. Tilly and Patricia Gurin. New York: Russell Sage.

$\rightarrow$ Galanter, Marc. 1974. "Why the 'Haves' Come Out Ahead: Speculations on the Limits of Social Change." Law and Society Review 9 (1): 95-160.

$\rightarrow$ Gamson, William, and Andre Modigliani. 1989. "Media Discourse and Public Opinion on Nuclear Power." American Journal of Sociology 95 (1): 1-37.

$\rightarrow$ Gibson, James. 1978. "Judge's Role Orientations, Attitudes, and Decisions: An Interactive Model." American Political Science Review 72 (3): 911-24.

Gilligan. Carol. 1982. In a Different Voice. Cambridge, Mass.: Harvard University Press.

Goldstein, Leslie Friedman. 1989. The Constitutional Rights of Women. Madison: University of Wisconsin Press.

Huckle, Patricia. 1982. "The Womb Factor: Pregnancy Policies and Employment of Women." Pp. 144-61 in Boneparth, ed.

Kalman, Laura. 1986. Legal Realism at Yale. Chapel Hill: University of North Carolina Press.

Kay, Herma Hill. 1985. "Models of Equality." University of Illinois Law Review 85 (1): 39-63.

Kerber, Linda K. 1998. No Constitutional Right to Be Ladies. New York: Farrar, Straus, \& Giroux.

Kirp, David, Mark Yudof, and Marlene Franks. 1986. Gender Justice. Chicago: University of Chicago Press.

$\rightarrow$ Law, Sylvia. 1984. "Rethinking Sex and the Constitution." University of Pennsylvania Law Review 132 (5): 955-1013. 
$\rightarrow$ Littleton, Christine. 1987. "Reconstructing Sexual Equality." California Law Review 75 (4): 1287-1337.

$\rightarrow$ Llewellyn, Karl. 1931. "A Realist Jurisprudence: The Next Step." Columbia Law Review 30: 431-62.

$\rightarrow$ Loseke, Donileen. 1997. "The Whole Spirit of Modern Philanthropy: The Construction of the Idea of Charity." Social Problems 44 (4): 425-44.

- 1999. Thinking about Social Problems. Hawthorne, N.Y.: Aldine de Gruyter.

MacKinnon, Catharine. 1979. Sexual Harassment of Working Women: A Case of Sex Discrimination. New Haven, Conn.: Yale University Press.

Matthaei, Julie A. 1982. An Economic History of Women in America. New York: Schocken.

McCloskey, Robert. 1994. The American Supreme Court. Chicago: University of Chicago Press.

Nowak, John E., and Ronald D. Rotunda. 1995. Constitutional Law. St. Paul, Minn.: West.

Otten, Laura. 1993. Women's Rights and the Law. Westport, Conn.: Praeger.

Pruitt, Lisa. 1994. "A Survey of Feminist Jurisprudence." University of Arkansas at Little Rock Law Journal 16 (2): 183-205.

$\rightarrow$ Rochefort, David, and Roger Cobb. 1993. "Problem Definition, Agenda Access, and Policy Choice." Policy Studies Journal 21 (1): 56-71.

$\rightarrow$ Romero, Francine Sanders. 2000. "The Supreme Court and the Protection of Minority Rights." Law and Society Review 34 (2): 291-313.

Rosenberg, Gerald N. 1991. The Hollow Hope: Can the Courts Bring About Social Change? Chicago: University of Chicago Press.

Schubert, Glendon. 1965. The Judicial Mind: The Attitudes and Ideologies of Supreme Court Justices, 1946-1963. Evanston, Ill.: Northwestern University Press.

$\rightarrow$ Segal, Jeffrey. 1984. "Predicting Supreme Court Cases Probabilistically: The Search and Seizure Cases, 1962-1984." American Political Science Review 78 (4): 891-900.

$\rightarrow$ Segal, Jeffrey, and Albert Cover. 1989. "Ideological Values and the Votes of U.S. Supreme Court Justices." American Political Science Review 83 (2): 557-65.

Segal, Jeffrey A., and Harold J. Spaeth. 1993. The Supreme Court and the Attitudinal Model. Cambridge: Cambridge University Press.

Seymour, Stephanie. 1997. "Women as Constitutional Equals: The Burger Court's Overdue Evolution.” Tulsa Law Journal 33:23-40.

$\rightarrow$ Sheehan, Reginald, William Mishler, and Donald Songer. 1992. "Ideology, Status, and the Differential Success of Direct Parties before the Supreme Court." American Political Science Review 86 (2): 464-71.

Skocpol, Theda. 1995. Social Policy in the United States. Princeton, N.J.: Princeton University Press.

Songer, Donald. 1999. "Do the Haves Come Out Ahead over Time? Applying Galanter's Framework to Decisions of the U.S. Court of Appeals, 1925-1988." Law and Society Review 33 (4): 811-31.

$\rightarrow$ Songer, Donald R., and Reginald S. Sheehan. 1992. "Who Wins on Appeal? Upperdogs and Underdogs in the United States Courts of Appeals." American Journal of Political Science 36 (1): 235-58.

Spector, Malcom, and John Kitsuse. (1977) 1987. Constructing Social Problems. Hawthorne, N.Y.: Aldine de Gruyter.

$\rightarrow$ Stone, Deborah. 1989. "Causal Stories and the Formation of Policy Agendas." Political Science Quarterly 104 (2): 281-300.

$\rightarrow$ Sunstein, Cass. 1996. "Law, Economics, and Norms: On the Expressive Function of Law." University of Pennsylvania Law Review 144 (5): 2021-53.

Supreme Court of the United Sates. 2002. Members of the Supreme Court (1979 to Present). Available on-line at http://www.supremecourtus.gov/about/about.html.

Walsh, Amy. 1998. "Ruth Bader Ginsberg: Extending the Constitution." John Marshall Law Review 32:197-225.

Wandersee, Winifred D. 1988. On the Move: American Women in the 1970s. Boston: Twayne.

Wasby, Stephen L. 1988. The Supreme Court in the Federal Judicial System. 3d ed. Chicago: Nelson-Hall.

$\rightarrow$ Wheeler, Stanton, Bliss Cartwright, Robert Kagan, and Lawrence Friedman. 1987. "Do the 'Haves' Come Out Ahead? Winning and Losing in State Supreme Courts." Law and Society Review 21 (3): 410-45.

Williams, Wendy Webster. 1984. "Equality's Riddle: Pregnancy and the Equal Treatment/ Special Treatment Debate." Review of Law and Social Change 13 (2): 325-80. 


\section{Supreme Court on Gender Discrimination}

1992. "The Equality Crisis: Some Reflections on Culture, Courts, and Feminism." Women's Rights Law Reporter 14 (2-3): 175-93.

Yalof, David Alistair. 1999. Pursuit of Justices: Presidential Politics and the Selection of Supreme Court Nominees. Chicago: University of Chicago Press.

$\rightarrow$ Yoo, John C. 2000. "Choosing Justices: A Political Appointments Process and the Wages of Judicial Supremacy." Michigan Law Review 98 (6): 1436-67.

\section{Notes}

1. Reed involved a challenge to a state law that gave men preferential treatment as administrators to an estate when several people, both male and female, were equally entitled to become administrators. The Court held that the law violated the Equal Protection Clause of the Constitution.

2. Although the 1960s saw the passage of two pieces of legislation crucial to women, the Equal Pay Act of 1963 and the Civil Rights Act of 1964, these pieces of legislation were not as feminist centered as might first appear. The Equal Pay Act, which was first introduced in 1945, took 18 years to pass and was designed to help men as much as women. Requiring equal pay for women was viewed as a way of protecting men's jobs, since it discouraged businesses from hiring women instead of men because they could pay them less, a practice begun during World War II (Freeman 1990). Similarly, the Civil Rights Act was not designed primarily for women, but for minorities. The proposal to add gender discrimination was a tactical decision designed to derail the act. It was met with derision, was little debated, and to the surprise of many, passed (Freeman 1990).

3. Thus, while many of the justices were new, the Court remained mostly stable throughout the rest of the decade studied, with the cases being decided by the same cohort of eight justices. The only significant change was when Justice Stevens replaced Justice Douglas in 1975. The first female justice, Sandra Day O'Connor, was appointed in September of 1981 and took part in two of the cases discussed here, an insufficient number to draw any conclusions on her impact.

4. The legal realist movement had its origins in the 1920s as various scholars reacted to a rule-bound and formalistic style of jurisprudence. It challenged the notion that law and judicial decision making were a rational, neutral enterprise. It attempted to unite social sciences and law, using the legal system as a way to achieve social justice. Its earliest proponents were Karl Llewellyn (1931) and Jerome Frank (1949).

5 . This method was also chosen rather than the common legal method of studying the Court according to the term of its chief justice because such terms do not necessarily correspond to distinctive political and social stages but are a function of when vacancies occur for the chief justice's position.

6. Unless otherwise indicated, if both the majority and concurrence in a particular case utilize substantially the same frame, no distinction is made, and both are referred to either as the "majority" or "the Court." When they differ in their approach, the difference is so noted.

7. A vote was considered profeminist if the outcome could be characterized under the equality frame or the difference theory frame as those terms are defined in the feminist and legal scholarly literature. In other words, a profeminist outcome was one where the result required men and women in similar situations to be treated the same, permitted a remedy for past discrimination against women, or compensated women for the unequal consequences that result from biological or cultural differences. All other outcomes were considered antifeminist votes.

8. The Court, at times, sounded like it was delivering a history lesson or sermon on discrimination. For example, relying on the nonlegal literature, including social science and historical research and findings of various task forces on the status of women, it described the long history of discrimination against women in all areas of life, noting that "throughout much of the 19th century the position of women in our society was, in many respects, comparable to that of blacks under the pre-Civil War slave codes" (Frontiero, p. 685 ). It exhorted society to brush aside "archaic and overbroad stereotypes" (Wiesenfeld, p. 643) and "myths and purely habitual assumptions about a woman's inability to perform certain kinds of work" (Manhart, p. 707). It also acknowledged "discrimination in our educational institutions, in the job market and perhaps most conspicuously, in the political 
arena" (Frontiero, p. 686). It even bemoaned the fact that there were no women justices on the Supreme Court.

9. In 1973, for example, over half of employed women were in traditionally female occupations, such as teaching and nursing. Only 14 percent were in professional occupations (Wandersee 1988).

10. The Court's decision had its limits. The Court stopped short of a general endorsement of the concept of comparable worth. This concept began to gain support in the 1980s and provides that jobs do not have to be equal, but comparable in overall effort, skills, responsibility, and working conditions (Goldstein 1989).

11. Nor can the outcomes be attributed to the shifting votes of a few justices in a closely divided Court. Satty was decided by a $9-0$ vote; Gilbert by a 6-3 vote.

12. It is somewhat difficult to reconcile the Satty decision with the outcome in Ford, the only other seniority case. The Court did not appear concerned, as it was in Ford, that male employees would resent the seniority granted to female workers. The distinction may have been that in Satty, the women had lost actual seniority accrued while working, while in Ford the seniority would have been granted to them without ever working a day at Ford (albeit because of discrimination).

13. On a practical level, the sheer cost of pregnancy disability coverage, a fact mentioned in the majority's opinion, might have discouraged them from mandating coverage. However, cost did not appear to influence the outcome in Turner, which required the state to expend considerable funds to cover pregnant women under state unemployment insurance programs.

14. This outcome stands in sharp contrast to Satty, the seniority case where women's difference required compensation because of its unequal consequences in the workplace. The concurrence in Satty attempted to reconcile it with Gilbert by noting that seniority rights affected women post pregnancy, after they returned to work. Williams (1984) makes a similar distinction, explaining the difference in the two rulings by characterizing seniority as a benefit accumulated before women become pregnant, and hence not an extra benefit based on pregnancy.

15. The Court's decision caused an uproar, with some lower courts and state human rights agencies expressly ignoring the decision. It also bucked a trend by state governments throughout the 1970 s that required employers to include pregnancy in their disability coverage (Huckle 1982).

16. In an unusual application of the difference theory frame, the dissenting justices argued in Hogan against admitting men because an all-female environment was often beneficial to women. Echoing the primary thrust of the difference theory frame, several of the dissenting justices (among them some of the justices who consistently voted against women's rights) argued that women needed a supportive and less sexist learning environment to counteract culturally imposed role expectations that had negative consequences for women.

17. This decision provoked a sharp dissent, with the dissenting justices stating that the majority's rationale perpetuated "one of the most insidious of the old myths about women-that women, wittingly or not, are seductive sexual objects" (Dothard, p. 344) and showed that the "pedestal upon which women have been placed . . . upon closer inspection, has been revealed as a cage" (p. 344). It accused the majority of engaging in romantic paternalism because it prevented women from making their own employment choices. It should be noted however, that the prison in question was one of the most "barbaric and inhumane" in Alabama (p. 342), putting it in violation of the Constitution. This may have contributed to the majority's decision, although it does not explain the language of it.

18. Legally, the distinction between strict scrutiny and rational basis is very significant (Nowak and Rotunda 1995). A law tested against the rational basis standard is easier to uphold, while one measured against a strict scrutiny standard is more likely to be struck down.

19. See n. 15 .

20. This form of equality can be traced to the writings of Catherine MacKinnon (1979), who argued that neither formal nor substantive equality was sufficient and that inequality had its genesis in norms of male power. According to MacKinnon, this power was sexually coercive and routinely and systematically used to subordinate women. As a manifestation of this power, sexual harassment had to be removed from the workplace for true equality between men and women to exist. 